\section{Lembaran} Sejarah
ISSN:

1410-4962
Page

157-178

\title{
Ersatz Capitalism in Indonesian Automotive Industry during The New Order Era, 1969-1998
}

\section{INSAN PRADITYA ANUGRAH}

Universitas Indonesia

\begin{abstract}
This paper examines a historical trajectory using Kunio Yoshihara's concept of ersatz capitalism to analyze the development of Indonesian automotive Industry during New Order Era, 1969-1998. The concept analyzes the fact that the ersatz capitalism structure and ersatz capitalists behavior had caused the failure of Indonesian automotive Industry development to achieve self-reliance. Ersatz Capitalism is characterized by patronage between capitalists and bureaucrats, the capitalists reluctance to invest in research and technological development, foreign capital and foreign technology domination, and the domestic capitalists role that act only as a distributor of the manufactured high-technology products of foreign principals instead of doing research and development, in order to seek immediate high profit return with minimum investment. Through the research, this paper analyzes the role of the ersatz capitalists from the various background such as military, Chinese capitalists, and president families and relatives had supported foreign principal domination In Indonesia. Those capitalists are reluctant to support government programs toward self-reliance industry and choose to strengthen their ties with foreign principals, in order to get immediate profit return without much investment and technological research.
\end{abstract}

\begin{abstract}
Abstrak
Artikel ini melihat trayek sejarah menggunakan konsep ersatz capitalism-nya Kunio Yoshihara dengan menganalisis perkembangan industri otomotif Indonesia semasa era Orde Baru, 1969-1998. Konsep ini menganalisis kenyataan bahwa struktur kapitalisme ersatz dan perilaku kaum kapitalis ersatz mengakibatkan kegagalan industri otomotif Indonesia dalam mencapai kemandirian. Kapitalisme ersatz diwarnai dengan hubungan patronase antara kapitalis dengan kaum birokrat yang menyebabkan keengganan dari kapitalis untuk menanam modal untuk riset dan teknologi, dominasi modal dan teknologi asing, serta terbatasnya peran-serta kapitalis domestic sebagai distributor dari produk manufaktur berteknologi tinggi prinsipal asing tanpa harus melakukan penelian dan pengembangan produk dalam negeri. Hal ini memungkinkan mereka untuk mendapatkan keuntungan (return) besar dengan investasi kecil. Melalui penelitian, artikel ini menganalisis peran-serta kapitalis ersatz dari beragam latar belakang seperti kaum militer, kapitalis Tionghoa
\end{abstract}

Keywords: capitalism; foreign investment; automotive industry

Kata Kunci: kapitalisme; investasi asing; industri otomotif 
dan keluarga presiden sehingga mendukung dominasi prinsipal asing di Indonesia. Kaum kapitalis demikian cenderung tidak mendukung program pemerintah yang mendorong kemandirian industri melainkan memilih untuk menguatkan ikatan mereka dengan prinsipal-prinsipal asing sehingga bisa meneruskan pendapatan keuntungan besar tanpa harus melewati usaha investasi penelitian teknologi.

\section{Preface}

Achieving "self-reliance" in Indonesian automotive industry has become an important topic of conversation since the early New Order era. Today Indonesia still depend on capital and technology assistance from abroad. Technological transfer had been planned by the New Order government through the deregulation of entry barriers either for CBU (Completely Built-Up) or CKD (Completely Knocked Down) in 1969 (PP No.6 1969) and the components localization program through the Industrial Ministry's decision of 1976 and the Presidential Instruction no. 21996 on the national car program. However, until the end of New Order era, Indonesia had never been able to achieve self-reliance in the automotive Industry. The inability to master technology is the main problem. This is caused by the ersatz capitalist structure of the automotive industry that tends to preserve technological and capital dependency to the foreign principals.

According to Kunio Yoshihara on ersatz capitalism in Southeast Asia (Yoshihara, 1990:2), Southeast Asian capitalist are unlike the capitalist class in Europe and United States who began their industrial business from the early stages of the production process with investment in research and development to increase the quality of the products. This research and development process allows the capitalists to become an agent of modernization for their country. The capitalist class in Southeast Asia were designed by the state to support the nationalization of foreign enterprises to the local ownership. State bureaucrats appointed various groups close to them, usually people from the ruling party or the military groups, to own the businesses. These appointments were without consideration of business background and experience in the industry. Consequently, these capitalists had no intention to support technological research and development and, as a result, could not be an agent of modernization for their own country (Yoshihara, 1990: 3-4).

During the first five-year development program (REPELITA I) the New Order government stated that the development of high-technology industry was a priority. The technological transfer was needed to support state plan toward the Technological-Minded society in order to prepare human resources to attract foreign investment (REPELITA I Jilid 2: 49). Those rules were important to raise the independent local sub-components and components industry in Indonesia such as paint, tires, battery, etc. 
Independent components industries itself are important for national enterprises as the early step toward mastering technology from upstream industries, before going further to the downstream industries. Thus, components industries are supposed to be separated from the assembly line, which was controlled by the foreign principals.

The relationship between capitalists and bureaucrats was an important factor in determining which groups get the access to the sole agent licenses. Chinese-Indonesian capitalists such as William Suryadjaya got his business opportunity from General Soerjo. He also obtained a joint venture with Toyota by the effort of Director of Engine and Metal Department of Industry, Ir. Soehartoyo. Liem's relationship with Soeharto's family allowed him to take over several enterprises from old lines capitalists who grew in Soekarno's era. Liem also got the Nissan sole agency from the military group PEPABRI when PEPABRI failed to manage PT. Wahana Wirawan.

Since the early 1980s, Liem Sioe Liong and William Suryadjaya emerged as two major Chinese-Indonesian capitalists who owned the franchise of various automotive brands (Astra owned 8 brands, and Indomobil owned 5 brands). However, in terms of industrial development, they preferred to let foreign principals, especially Japanese manufacturers, to tightly control the technological development. The proliferation of Astra and Indomobil branch companies in component industries are evidence of foreign principals vertical integration from components industries to assembly industries. Foreign domination rose significantly in the early 1980s when foreign, especially Japanese, principals invested in production facilities for the main components.

During 1969 to early 1990s, there were various projects which were held to support government program on technological transfer and human resources development of industry, such as the assembly line of KBNS project (Kendaraan Bermotor Niaga Sederhana/Low-Cost Motorized Vehicle for Business) in the 1970s, that was also supported by various local component industries. There were also several unfinished projects by Subronto Laras, manager of Indomobil, in the late 1980s and in the 1990s. Indomobil claimed the Mazda MR90 as a national car despite buying the license from Mazda. Later on, in the early 1990s, the Maleo car that was developed by Minister of Technology B.J. Habibie and Beta 97 by PT Bakrie Motors were technological transfer efforts using a multi-sourcing system, instead of merely licensing from foreign principals.

\section{What is ersatz capitalism?}

Ersatz capitalism was stated by Kunio Yoshihara in the 1980s, The word "ersatz is originally taken from the German language that means"substitution". This word is used in English in a little bit different meaning, as "more inferior 
substitution”. According to Kunio Yoshihara, the ersatz capitalism structure is not real capitalism, but only a more inferior substitution (Yoshihara, 1990: xiii). "Real" capitalism refers to the free business ownership, meanwhile, the capitalists produce goods by their own capital, take the responsibility, competing for business with each other and doing research and development for their industrial products by doing various innovations in order to win the business competition to their rivals. Based on their innovation, the capitalists must be an economic modernization agents for their own countries, as we can see in various countries such as Europe, United States, Japanese, and South Korea (Yoshihara, 1990: 3-4).

In Southeast Asia, local capitalist mostly obtains concessions given by the government based on their personal relations with the state bureaucrats and not based on their business acumen. The capitalist class was formed by the state as a result of nationalist sentiments and business localization policy (pribumisasi). In consequence, these capitalists lacked competence and experience to run a modern and high technology industrial business. They capitalists were highly dependent on state facilities in business activities, and consequently the capitalist class reluctant to take a risk in the business.

In the colonial period, The Netherlands East Indies government did not allow local capitalists to take part in high-technology industrial sectors including automobile industries and other manufacturers. The capital and technological dependency to the foreign principals makes Indonesian capitalists seek state facilities and supports in order to get an immediate high return (Ian Brown, 199: 265). The Indonesian capitalists simply took the role of assembler and distributor partner of foreign principals (comprador), as well as rent-seeker and business speculators who only seek for state facilities and protection. They are reluctant to take a role as modernization agent for their own country through research and development as western capitalists did.

Unlike the capitalists in Europe, United States, and Japan, the capitalists class in Southeast Asian rose when the world economic structure was already relatively integrated, in which the industrialized countries dominate the world economy, and tend to preserve underdeveloped countries as their marketplace. This condition requires capitalists in Southeast Asia to catch up what established capitalists in developed countries already achieved. As very much capital and extra efforts needed to achieve self-reliance in the automotive industry, the local capitalists were likely to maintain good relations and tend to accommodate foreign principals interest to preserve their distributorship and assembly business to get the immediate high return (Brown, 1997: 265).

As Kunio has explained, the main challenges faced by Southeast Asian capitalists are capital ownership, the accessibility to the foreign market, and 
mastering high-technology. Therefore, we can see ersatz capitalism has been formed by the business practice through these four important aspects below:

1. Patronage between capitalists-bureaucrats and capitalists rentseeking practice.

2. The reluctance of the capitalists to invest in technological development. Capitalists are too worried that they will not be able to compete for the established capitalists from developed countries.

3. Foreign principals determination in technological development and lack of technological innovation by local capitalists.

4. Capitalists role that acts only as comparator who seek for mere immediate high-profit return.

Based on the definition, every capitalist who run their business on foreign capital and foreign technology, and they act only as a trader with distributorship license of a foreign manufactured product is ersatz capitalists.

\section{Group of Capitalists in automotive industry}

During New Order era, there were three groups of capitalists who dominate automotive Industry, e.g.: 1) Chinese-Indonesian capitalists, 2) Military groups, 3) President's family. From 1969 to the last 1980s, the military and Chinese-Indonesian groups became the predominant capitalists' group in the automotive industry. Both, military and Chinese-Indonesian groups were preferred by mainly Japanese foreign principals as business partners. Since the mid-1960s, the Army doctrine of Dwifungsi made it possible for military officers to participate in politics and business activities (Harold Crouch: 24-25). Military groups such as Ibnu Sutowo (Kramayudha \& German Motors), Sjanurbi Said (Kramayudha), Hasjim Ning (Hasjim Ning Group), and various business institution belongs to the military institutions such as KOSTRAD which was owned PT. Garuda Mataram, and PEPABRI which was owned PT. Wahana Wirawan.

Chinese-Indonesian capitalists were also important regime to accelerate economic growth because of their business skill as one of the main economic agents since the colonial period. The Government hoped that the Chinese groups would attract foreign investment to the country. Both of Chinese capitalists and military groups were also preferred by foreign principals especially Japanese, compared to the "Benteng line capitalists" who frequently appeared as arrogant "nationalist" especially when they faced the Japanese principals.

The Chinese capitalists dominated auto Industry such as Liem Sioe Liong with Indomobil groups, Hadi Budiman (Ang Kok Ha) with Prospect Motor, Atang Latief (A Piang) with PT. Indohero (before acquired by 
Liem into Indomobil) and William Soeryadjaja with Astra Group. These Chinese-Indonesian groups developed since the colonial period but had not gone into the high-technology sector. Their business was based on concessions obtained from the military officer and bureaucrats whom they had befriended.

Willliam Soeryadjaya got his business license from General Soerjo. William also maintained a close relationship with Pertamina Director and automotive businessman General Ibnu Sutowo, President Soeharto's cousin Probosutedjo and the economist Sumitro Djojohadikusumo. The most important people for Astra business was Ir. Soehartoyo, the head of metal and machine directorate who initiated a joint venture between Astra and Toyota in 1971. As a return, William gave Soehartoyo position as a board director in Astra.

Another Chinese capitalist Liem Sioe Liong had close relations with the Diponegoro Division, a military division led by General (later President) Soeharto during the revolutionary and early independence period. He owned PT. Central Sole Agency, a sole agent for the Swedish luxury automaker Volvo. Liem's family expanded their business in the automotive industry in the mid-1980s as they bought Indohero Suzuki from Atang Latief and hired his skillful manager, Soebronto Laras. Subronto later became the key role of Liem's family business success in the automotive industry.

In the 1980s, by President Soeharto's recommendation, Liem's family succeed to take over PT. Wahana Wirawan, a Nissan sole agent and assembler company which was previously owned by PEPABRI. Other Chinese capitalists were Atang Latief (A Piang) who owned the Suzuki sole agent PT. Indohero, but later his business was taken over by Liem's group. Another Chinese capitalist was Hadi Budiman (Ang Kok Ha), he owned PT. Prospect Motors, the sole agent, and assembler of Honda in Indonesia.

On one hand, military groups were "indigenous" representatives and a symbol of guarantee from the regime to the foreign principals and vice versa. Military groups tend to back up the Chinese capitalists from anti-Chinese sentiments in the country. Unlike the Chinese groups that had a business skill and experience, military groups had not much capital, experience, and business skill (Miet Sugiarso: Interview). Military groups were more dependent to foreign principals than the Chinese groups. That is why PT. Kramayudha, which was owned by General Sutowo became the first sole agents that ask Mitsubishi principals to invest in the components localization in the 1970s.

On the other hand, the Chinese groups are important for the military groups to get capital and managerial aid, as in the case of PT. Wahana Wirawan's PEPABRI that lack of capital and business skill to develop their business. PEPABRI was asked for aid from Liem groups which was the 
Tabel 1.

Ownership of automotive industry during 1981-1990

\begin{tabular}{|c|c|c|c|}
\hline Company & Principal & Shares & Information \\
\hline PT. Krama Yudha & Mitsubishi & $\begin{array}{l}\text { Japanese share unknown, } \\
\text { Sjanurbi Said held } \\
\text { dominant domestic share } \\
\text { in } 1984\end{array}$ & $\begin{array}{c}\text { A share of } \\
\text { PT.Mitsubishi } \\
\text { Kramayudha Motor } \\
\text { and Manufacturing } \\
\text { 80\% Japanese, } \\
\text { PT. Colt Engine } \\
\text { Manufacturing } 80 \% \\
\text { Japanese }\end{array}$ \\
\hline $\begin{array}{l}\text { PT. Indomobil } \\
\text { Utama (Group } \\
\text { Salim) }\end{array}$ & $\begin{array}{l}\text { Suzuki, Market } \\
\text { Share }\end{array}$ & $\begin{array}{l}\text { Dominated under } \\
\text { management of Liem Sioe } \\
\text { Liong }\end{array}$ & \\
\hline $\begin{array}{l}\text { PT. Central Sole } \\
\text { Agency (Group } \\
\text { Salim) }\end{array}$ & Volvo, Market Share & $\begin{array}{c}\text { Dominated by Salim, } \\
\text { with composition Sudono } \\
\text { Salim (Liem Sioe Liong) } \\
\text { 15\%, Sudarmo Salim } \\
\text { 15\%, Albert Halim 15\%, } \\
\text { Ibrahim Thahir 15\%, } \\
\text { Wanita Winj 15\%, Liem } \\
\text { Suhanda 15\% }\end{array}$ & $10 \%$ unknown share \\
\hline $\begin{array}{l}\text { PT. Tjahaya Sakti } \\
\text { Motor (Group } \\
\text { Hasjim Ning)* }\end{array}$ & BMW & $\begin{array}{c}\text { Hasjim Ning 20\%, Yasrin } \\
\text { Yasin 50\%, Toto Bachrie } \\
20 \%\end{array}$ & $\begin{array}{c}\text { 10\% unknown. In } \\
\text { 1984, the share } \\
\text { dominate by William } \\
\text { group }\end{array}$ \\
\hline $\begin{array}{l}\text { PT. Tjahaya Sakti } \\
\text { Motor (Group } \\
\text { Astra)* }\end{array}$ & BMW & $\begin{array}{c}\text { PT. Multi France } \\
\text { (Group Astra) 50\%, PT. } \\
\text { Ningz dan rekan 21\%, } \\
\text { Soegianto 5\%, Yasrin } \\
\text { Yasin 5\% }\end{array}$ & $\begin{array}{c}\text { Taken over by } \\
\text { William since } 1984\end{array}$ \\
\hline $\begin{array}{l}\text { PT. National Motor } \\
\text { (Group Hasjim } \\
\text { Ning) }\end{array}$ & Hino dan Mazda & $\begin{array}{c}\text { Hasjim Ning, Bachtiar } \\
\text { Lubis }\end{array}$ & \\
\hline $\begin{array}{l}\text { PT. National Motor } \\
\text { (Group Salim)* }\end{array}$ & Hino dan Mazda & $\begin{array}{l}\text { 60\% belong to Salim } \\
\text { (Liem Sioe Liong) }\end{array}$ & \\
\hline $\begin{array}{l}\text { PT. Wahana } \\
\text { Wirawan* }\end{array}$ & Nissan /Datsun & $\begin{array}{l}\text { Gen. Sukardi (Pepabri) } \\
\text { 56\%, NY. Affan 33\%, } \\
\text { Soegiarso } 11 \%\end{array}$ & $\begin{array}{c}\text { Share between } \\
\text { 1981- } 1984\end{array}$ \\
\hline $\begin{array}{l}\text { PT. Wahana } \\
\text { Wirawan (Group } \\
\text { Salim)* }\end{array}$ & Nissan /Datsun & Dominate by Liem's group & \\
\hline PT. Imer UD* & Nissan UD (Truck) & $\begin{array}{c}\text { PT. Imermotor } 70 \% \text {, Ibnu } \\
\text { Tadji } 25 \%\end{array}$ & $5 \%$ unknown \\
\hline
\end{tabular}




\begin{tabular}{|c|c|c|c|}
\hline $\begin{array}{l}\text { PT. United Imer } \\
\text { Motor* (Group } \\
\text { Astra) }\end{array}$ & Nissan UD (Truck) & $\begin{array}{l}\text { Astra Group } 80 \%, \text { PT. } \\
\text { Imermotor } 20 \%\end{array}$ & \\
\hline $\begin{array}{l}\text { PT. Toyota Astra } \\
\text { (Group Astra) }\end{array}$ & $\begin{array}{c}\text { Toyota (Market } \\
\text { Share 1979: } 27,3 \% \text { ) }\end{array}$ & $\begin{array}{c}\text { Toyota Jepang 48\%, PT. } \\
\text { Astra Internasional } 36 \% \text {, } \\
\text { PT. Gaya Motor } 15 \%\end{array}$ & $\begin{array}{c}\text { Joint venture since } \\
1971\end{array}$ \\
\hline $\begin{array}{l}\text { PT. Daihatsu } \\
\text { Indonesia } \\
\text { Manufacturing } \\
\text { (Group Astra) }\end{array}$ & $\begin{array}{l}\text { Daihatsu (Market } \\
\text { Share 1979: 5,8\%) }\end{array}$ & $\begin{array}{l}\text { PT. Astra Internasional } \\
70 \% \text {, Jepang } 30 \%\end{array}$ & since 1979 \\
\hline $\begin{array}{l}\text { PT. Multi France } \\
\text { (Group Astra dan } \\
\text { Probosutedjo) }\end{array}$ & $\begin{array}{l}\text { Peugeot Market } \\
\text { Share 1979: 0,3\%, } \\
\text { Renault Market } \\
\text { Share } 1975: 0,1 \% . \\
\text { Gabungan 0,4\% }\end{array}$ & $\begin{array}{l}\text { PT. Multivest } 70 \% \text {, } \\
\text { Probosuetedjo 25\%, Nn } \\
\text { Siti Pujiani 5\% }\end{array}$ & $\begin{array}{c}\text { Established in } \\
\text { 1972, 60\% share } \\
\text { hold Soeryadjaya's } \\
\text { Family }\end{array}$ \\
\hline $\begin{array}{l}\text { PT. Djakarta } \\
\text { Motors (Group } \\
\text { Hasjim Ning) }\end{array}$ & $\begin{array}{l}\text { SIMCA, AMC (Jeep) } \\
\text { Market Share 1979: } \\
\text { 0,1\%, Chrysler } \\
\text { (Dodge) Market } \\
\text { Share 1979:0,3\%. } \\
\text { Total 0,4\% }\end{array}$ & $\begin{array}{c}\text { Ibnu Sutowo 40\%, Hasjim } \\
\text { Ning 39\%, Bachrie: } 19 \% \text {, } \\
\text { unknown } 2 \%\end{array}$ & $\begin{array}{l}\text { merger with Ibnu } \\
\text { Sutowo in } 1972\end{array}$ \\
\hline $\begin{array}{c}\text { PT. IRMC } \\
\text { (Indonesia } \\
\text { Republik Motor } \\
\text { Company) (Group } \\
\text { Hasjim Ning) }\end{array}$ & $\begin{array}{l}\text { Land Rover (Market } \\
\text { Share } 19790,2 \% \text {, } \\
\text { Morris dan Leyland } \\
\text { market share under } \\
0,1 \%, \text { Ford market } \\
\text { share 0,8\%. Total } \\
\text { market share 1\% }\end{array}$ & $\begin{array}{c}\text { Ownership since } 1976 \\
\text { Ny Ali Murtopo (Yayasan } \\
\text { Harapan Kita) } 10 \%, \text { Saso } \\
\text { Sugiarso 10\%, about } 80 \\
\% \text { ownership remains } \\
\text { unknown but suspected } \\
\text { owned by Hasjim Ning } \\
\text { group. }\end{array}$ & \\
\hline $\begin{array}{l}\text { PT. Daha (Group } \\
\text { Hasjim Ning) }\end{array}$ & $\begin{array}{c}\text { Fiat Market Share } \\
1979: 0,2 \%\end{array}$ & $\begin{array}{c}\text { Hasjim Ning } 30 \% \text {, Agus } \\
\text { Dasaad } 30 \%, \text { PT. Ningz } \\
\text { dan Rekan (dominated by } \\
\text { Hasjim Ning) } 30 \% \text {, Italia } \\
10 \% .\end{array}$ & \\
\hline PT. Alun & Citroen & $\begin{array}{l}\text { Ny. Listy Sutiana } 60 \% \text {, } \\
\text { Hartanto Prasetia } 40 \%\end{array}$ & \\
\hline $\begin{array}{l}\text { PT. Garmak } \\
\text { (Group } \\
\text { Probosutedjo) }\end{array}$ & $\begin{array}{c}\text { Holden, GMC } \\
\text { (truck), Chevrolet, } \\
\text { Bedford }\end{array}$ & $\begin{array}{l}\text { Probosutedjo 72\%, NY. } \\
\text { Ratmani } 12 \%, \text { Nn. Diniarti }\end{array}$ & $\begin{array}{c}\text { Based on Share in } \\
1979\end{array}$ \\
\hline
\end{tabular}

Sumber: Chalmers: 328-341; Pamungkas: 192-193. Symbol *: acquisition. 
closest the Chinese group to Soeharto, to manage PT. Wahana Wirawan. The Decline of PEPABRI's share in that company had caused the Nissan sole agents acquisition by Indomobil group.

The members of president's family began their business in the auto industry since the 1970s when Probosutedjo had his merged with William Soerjadjaja to PT. Multifrance Motor in 1972, PT. Multifrance was a sole agent of two French manufacturer brands Peugeot and Renault (Ian Chalmers. 1996: 186), later in 1977 Probosutedjo owned the sole agent of Chevrolet dan Opel (Chalmers, 1996:228). In the 1990s the national car boom was followed by the decline of military groups and the rise of Soeharto's family. Just like military groups, Soeharto's family is a symbol of regime existence in the automotive business and as well the representative of indigenous capitalists.

National car projects such as Bimantara owned by Bambang Tri Hatmodjo and Timor by Tommy Soeharto, both sons of President Soeharto, used a license agreement from KIA Motors and Hyundai without any further development efforts. Former ministry of Industry in the 1960s stated both Tommy and Bambang had shown nationalist imagery through this project, but their projects were absolutely not related to the massive industrialization which was planned by Department of the industry before 1980s (Hadi, 2005: 248). In the case of Timor project, in 1996 government gave special facilities to protect TIMOR by freeing it from import duties.

\section{Fragmentation of State's Policy}

There were three state institutions with the different orientation towards automotive industries, the BPPT (State Body for Technological Research and Application under BJ Habibie), Department of Industry, and Directorate of Machine and Metal of Department of Industry. The directorate became the separate entity to the Department of Industry itself in terms of the way they took toward industrialization. BPPT basically wanted to build up an automotive industry from research and development, with the efforts to prepare high-technology minded human resources without technological transfer from any foreign principals, Department of Industry under Minister A.R. Soehoed preferred technological transfer step by step from the upstream line to downstream line of industries.

Soehoed also planned to diversify foreign principals based on their host country in order to prevent vertical integration and technological domination from upstream to downstream industries by one principal country. Therefore, a subcontract between independent sub-component industries and the assembly industries was needed in order to maintain the independent industries market. Department of Industry hoped that auto industry will be the sphere of industrial development in Indonesia (Chalmers, 1996:260-262). 
BPPT and Department of Industry's vision met in one point of view, and implemented in the Interdepartmental Team chaired by Prof. Rahardi Ramelan, both of them agreed to develop independent component industries as a first step, before taking over complete production from upstream to a downstream line. BPPT and Department of Industry agreed that they might not let foreign principals dominate Indonesian industrial sector by vertical integration (especially Japanese manufacturers). Therefore, diversification of foreign principals to provide technological assistance in component industries need to be diversified (Rahardi Ramelan: Interview). Diversification is also important to prevent principals from one hostcountry to dominate technology and capital in Indonesian auto-industry (Rahardi Ramelan: Interview).

BPPT and Department of Industry were also supporting Wahab Affan action to build the first complete production facilities in Indonesia. Affan opposed Nissan principals which tend to maintain technological dependency to the local partner. Affan used a loan from Marubeni (Nissan financial institution) and various Banks in Europe to realize complete production facilities in Indonesia which owned by the local capitalist (Miet Sugiarso: Interview). Affan is known as nationalist fashioned capitalist and anti-Japanese capital as well.

The third faction was the directorate metal and machinery led by Soehartoyo. They had supported automotive industrialization to be fully integrated with foreign principals (especially Japanese principals). In Soehartoyo's view, the Industrialisation and localization would be more efficient and faster to achieve by letting foreign principals build production facilities in components and main components industries, the subcomponents and components industries will be owned by branch companies of principal partners (assembler).

For Soehartoyo himself, to achieve automotive industrialization as soon as possible is important to impress President Soeharto, he tried to build imagery as a successful officer that push foreign principals and sole agents to support government "industrialization" and "localization" by invested capital in production facilities in Indonesia. For Soehartoyo, this is a necessary step that the country needs.

Department of Industry and BPPT as its allies opposed Directorate's policy to support the vertical integration of capital and technology by the foreign country, especially Japanese manufacture. Therefore, Minister of Industry, A.R. Soehoed, tried to limit directorate's power from policy maker to only become executor who might not be able to oppose the minister's plan. Directorate's role to determine automotive policy was replaced by Interdepartmental team or known as interdep team" which led by BPPT high-ranked officer, Ir. Rahardi Ramelan. The interdepartmental team was 
independent and responsible to do research and development toward future step of automotive industrialization.

President Soeharto gave Soehartoyo a new Post in BKPM, while Directorate's position filled by Eman Yogasara, Soehoed's ally and member of the Interdepartmental team (Rahardi Ramelan: Interview). However, Soehoed's dream towards industrialization from upstream independent industries become difficult to realize because Foreign Principals was already strong with their alliance with local partners.

\section{Coopted localisation}

As the early step developing automotive industry, in 1969 government had increased import tax through PP. No. 61969 (Wibowo, 1998: 55), as it is stated that every CBU (Completely Built Up) and SKD Semi Knocked Down) vehicles with the same type as assembled in Indonesia with CKD (Completely Knock Down) program were prohibited to enter Indonesia. In 1976, Government encourages component localization through PP 307/1976, which regulated commercial cars subjected to use local components. Localisation also followed by deletion programs for certain imported components, to be replaced by the local components (SK Menteri Perindustrian RI No.307 1976).

From 1975 to 1978 component localization were aimed to develop KBNS (Kendaraan Bermotor Niaga Sederhana). In that period, the production of KBNS had increased from $200 \%$ to $300 \%$. Almost all of karoseri production purposed to the buses, trucks, oplet, minibus, and staton wagon in 1978. It was estimated there were 200 karoseri manufacturers in Indonesia (Chalmers, 1996: 220-221). Basically, automotive industry (either components industries) or assembly industries can only grow by enough market capacity, but in the 1970s when auto brands in Indonesia improved very fast from 12 to 36 brands, while Indonesian market capacity did not accommodate the production growth (Chalmers, 1996: 212-214).

Brand rationalization which was proposed by Department of Industry to limit the inflow of automotive brands never succeeds, Government did not have the courage to limit foreign principals arrival in Indonesia, because many local partners who had close relations with state officials support the foreign principals to enter or to still exist in the country. Foreign Principals interests are supported by the local assembly partner, as Mitsubishi had supported by Kramayudha, while Kramayudha's bosses; General Soetowo and General Sjanurbi Said; are one of the had, people in the country. Toyota and Astra partner had supported by Director General of Metal and Machine, Soehartoyo, as Soehartoyo was also got a position as one of the boards of a director in Astra.

Localisation and deletion program was aimed to proliferate sub- 
components industries and the new capitalists that will own those industries as well. The government hopes there will be pyramids of production in an auto industry built by small business of component industries independent from foreign principals. Before late of the 1970s the New Order regime tended to support BPPT and Department of Industry plan to push independent local components industries and support Wahab Affan's effort toward complete automotive industrialization.

However, since Nissan principal won the dispute against Wahab Affan, the government changed their stance and Minister Soehoed was forced to follow Soehartoyo's plan towards integration to foreign principals. The regime finally agreed to let foreign principals invest in main components production facilities. Conglomeration and business concentration in assembly industries are in line with business conglomeration and concentration in components and sub-components industries, assemblers had built alliance with foreign principals to contend State's domination.

Government Instruction SK 3071976 about localization had failed to make sure that the sole agents supported localization program because it did not contain a guarantee that the assembler has an obligation to buy the components from independent industries. Meanwhile, the proliferation of independent components industries was not followed by its market purchase (Adnan, 2010: 92). Component Localisation has been co-opted by the principals because their local partners also had branch companies which produce "local components" based on principals direction.

Japanese principals had already denied certain independentmanufacture components such as velg, shock breaker, cabin, and silencer since it produced locally in 1977. Japanese principals didn't want to negotiate the component specification to complement the cars, they tended to preserve their own standard for the components and sub-components, as the consequence they only accept "local" components which produced by their branch industries. For example, Japanese principals deny local velg and silencer produced by two branches of independent local company PT. Udatin, which independent from principals and spread validation and reliability issues of independent local components. Gaikindo, the national automotive association who supported government program toward industrialization in the beginning, later support principals arguments about reliability and validation issues on independent local components (Chalmers, 1996: 222).

As change happened in Indonesian economy from 1982-1988. The fall of oil price caused the decrease of consumption and the growth of auto Industry, as well as independent components industries, became stuck (Adnan, 2010: 290). On the other hand, the market purchase is only about $75,000 \mathrm{car}$ in a year. The government should have limited the brands and assembly industries to guarantee market capabilities in order to preserve 
the existence independent sub-components and component industries. (Chalmers, 1996: 220-221)

This crisis made government more accommodative toward foreign investments, including investment in main components to sub-components. Various brands such as Volvo, Suzuki, Daihatsu, Toyota were able to integrate their capital and technology helped by the connection between their local partners to the bureaucrats. Meanwhile, Ang Kok Ha the owner of Prospect Motor even asked Honda Principal to invest in assembly and main component production from the beginning of their partnership.

In the 1980s there were about 42 automotive brands in Indonesia, 130 car types, and more than 20 assembly industries. The stuck economic condition has made an assembly manufacture can only make 20 cars in a month or about 240 cars a year, while the economic efficiency can achieve by producing at least 500 cars a year (Adnan, 2010:149). This condition affected brand rationalization and localization plan. Brand Rationalisation was difficult to implement in Indonesia due to conglomeration in the auto industry, as well as integration between principals and their domestic partners, and patronage between capitalists and state's bureaucrats.

In this condition, conglomeration in automotive industry had caused foreign principals joint in alliance with their local partners. They such as Lim Sioe Liong, with PT. Ismac, Ibnu Soetowo, and Jusuf with PT. German Motors, Ibnu Soetowo and Sjanurbi Said with PT. Mitsubishi-Kramayudha Motor \& Manufacturing, William Soeryadjaya with PT. Mobilindo and PT. Daihatsu Indonesia, Atang Latief with PT. Suzuki Engineering Indonesia. Each of them asked their principals such as Volvo, Mercedes, Mitsubishi, Toyota, Daihatsu, and Suzuki to build production facilities to produce main components production facilities, to face government pressure toward industrialization (Chalmers,1996: 229).

Foreign principals especially Japanese and their partners were successfully pushing Soehoed to let foreign principals invest in production facilities of main components (machine). In 1982, Toyota invested 39,4 Million US\$, Mitsubishi 141 Million US\$, Isuzu 29 Million US\$, Daihatsu 121 Million US\$, Daimler-Benz 29,5 Million US\$, Hino 33,3 Million US\$, and Suzuki 20 Million US\$ (Ian Chalmers, 1996: 289). The vertical integration of foreign capital and business conglomeration had caused proliferation of branch components industry related to the principals so that the principals surely would prefer to accept components from that branch rather than the independent components. This caused independent component business collapsed.

The vertical integration of foreign (Japanese) principals from upstream to downstream industries in 1982 was a "Total loss" for the government plan, in the beginning, to encourage and proliferate national capitalists in 
components industries and moves up step by step toward complete assembly line to achieve self-reliance of the automotive industry. The state was totally withdrawn from massive plan to achieve automotive industrialization which planned by Ministry of Industry and BPPT in 1969.

\section{Various projects toward industrialization 1970s - 1998}

KBNS (multi-purpose vehicles) was a government project in the 1970s to support the independent component industries. This project was forced by the government for various foreign brands, to build several multi-purpose vehicle variants such as Toyota Kijang, Datsun Sena, VW Mitra, and Holden Morina. The KBNS projects were stopped in the mid-1980s following the vertical integration of foreign principals in 1982. There were still various efforts to work on a national car project after 1982, but the efforts were merely sporadic from the high-ranked officers in Assembler Company. For example, Subronto Laras purchase license from reliance brand, and several secret projects to buy a license from European brands.

In the early 1990s, Mazda develops MR 90 as a national car project that was based on 1970s Mazda Capella. This car was merely a facelift version of Mazda Capella without much changes in the exterior (Suryanto Hariadi: Interview). This project was stopped due to failure getting government supports and production target (Subronto Laras: Bloomberg TV Interview).

\section{Subronto's Indonesian Silencer Secret Project: The reluctance of Indigenous}

According to the Former Indomobil Manager of Research and Development Mr. Suryanto Hariadi, Subronto Laras once ordered him to make a small project related to the research and development making a local silencer. As the first step of development, Suryanto needs to collect the data in the Suzuki Engine Industry to find out more about the result of the prototype. When Suryanto was going to do Dyno Test to get the data, the mechanics refused to give the data, as he argued that the specification are confidential and not accessible to any people except the principal officials itself. As Suryanto stated:

"Indonesians themselves are reluctant to seize the technology for their own country, each of them chose to keep the secret of Japanese technology, Japanese influence was extremely high. It means they (the engineers) give their loyalty to the Japanese, not to the country. (It is how) most of the Indonesian development enginers abandon their fields just a few years after work in the industry, they won't stay for a long time in the R\&D field”.

That was a clear example that the principals tend to preserve their domination and determination of the technological knowledge. The 


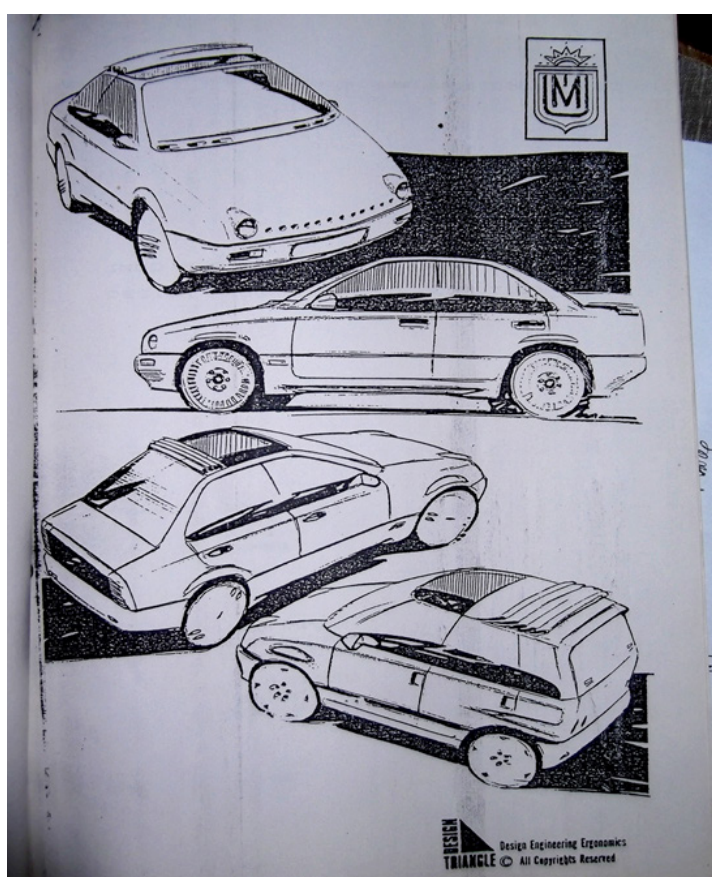

Figure 1.

Subronto Laras Secret Project Prototype principals also had the power to determine which components will be used by their production cars, and as well from which company they will order the components. Moreover, the low-rank local engineers were very loyal protecting principal's interest from high-ranked officer effort in developing the national manufactured product.

\section{Mafia Projects}

In the late 1980s, Subaronto Laras develop a fiberglass car named "reliance" with the Indomobil Team. The prototype car using the engine, transmission, and axle from Suzuki Swift with 1000cc engine capacity. Soebronto and Indonesian engineers had a big vision to build a brand-new Indonesian car. Indomobil developed the car using the ex-classic car (Marfia) factory in Tangerang. The development was separated from Indomobil in order to prevent Suzuki principal's reaction (Suryanto Hariadi: Interview).

To legalize this project, Indomobil had to buy the license from United Nations for about 5 Million US\$. It caused Indomobil to dismiss the project, as Soebronto Laras has stated in TV interview (Soebronto Laras: Bloomberg TV Interview):

"In 1994 Indomobil aided by reliance consultant from the United Kingdom in purpose to develop a national car. To register the new design, Indomobil must pay an expensive price to United Nations rules regulation to get the legal framework from various participant countries that owned the patent about protocol and technical regulations on automotive and component developments, they (Indomobil) had to pay 5 Million US\$, (as the consequence of the expensive patent) it (the project) just ended and merely an impossible dream to realize"

Despite the patent price was too expensive, the Indomobil Owner, Anthony Salim was vague about the car market purchase, he assumed that Indonesian were unlikely to buy a fiberglass car. He argued that Indonesian market was not ready yet to accept fiberglass production car. He assumed that people would not trust the ability of fiberglass car for daily use. 


\section{National car boom in the 1990s}

In the early 1990s, self-reliance in the auto industry became once again an important issue in the media, as the government needs to be high-technology oriented towards take-off economy. In this decade, we can see various newcomers in the auto industry, including president's sons Bambang and Tommy began their business in the automotive industry.

Beside President's sons, other new capitalists who decided to invest in the auto industry were Aburizal Bakrie and Marimutu Sinivasan. Even though the Spirit of self-reliance in the "Boom Mobil nasional" era was completely not related to localization program before the 1980s, but we could see that Various National car prototype had already designed and even tested in this period.

\section{Timor}

In 1996, President Soeharto appointed his own son to develop the only national car named "Timor" which the license was bought from Kia Motors. Governments officials informally urged to be stopped other development projects of the national car with similar market segmentation (Suryanto Hariadi: Interview). It was addressed to the other national car projects in Sedan variant, as the government argued that they need to concern in only one project. Many scholars and automotive observers argued that Timor was merely a "lipstick" project because in fact it was completely built up the car from Kia Motors Korea that had been given free duty facilities (Wibowo, 1998: 43).

Timor and Bimantara were using license agreement from the single principle on technological transfer (Mazda, Kia, Hyundai) while various projects such as Maleo, Beta97, and Truk Perkasa were national car project using multi-sourcing process. Only Maleo and Bakrie Beta97 used the non-principal technological transfer. Maleo and Bakrie Beta projects were relatively not seeking for state's special facilities. Certain projects such as MR90, Truk Perkasa, and Timor were developed with motivation to gain state

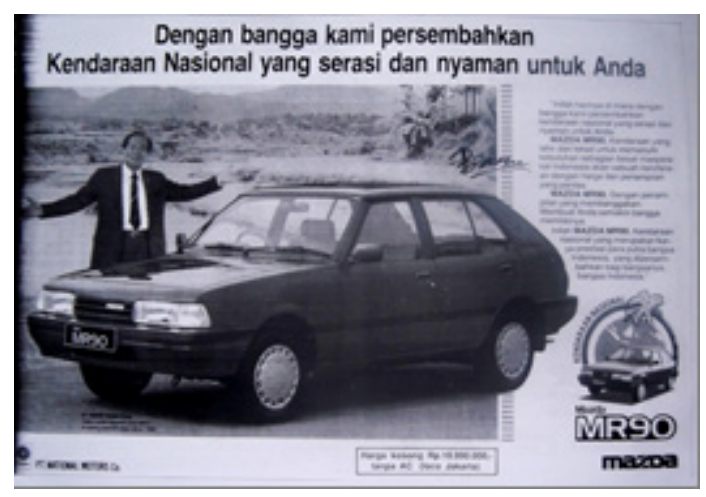

Figure 2. Mazda MR90. Developed by Indomobil protection facilities.

\section{Maleo Project}

In 1992 there was a cooperation project between BPIS and Java Motors, named Maleo Project, and piloted by B.J. Habibie, using multi-source components methods by license agreements assisted by Shado automotive consultant from the UK. Maleo Project was a consortium project between 
BPPT, PTN, Java Motors, and BPIS. This project was inspired by IPTN successful project buying a license from CASA Airplane. Maleo development step was exactly similar to IPTN, starting with buying the license and find some engine supplier, At the beginning, Maleo approach Honda and Rover to provide the engine, but later Maleo cooperated with Australian Orbital Engine Corporation, an engine manufacturing company originating from Australia. According to the plan, Maleo would be using an engine with displacement $1200 \mathrm{cc}$, the engine equipped with low pollution technology (http://carnews-online.blogspot.com/2011/04/maleo-indonesiasnational-car.html).

The chassis design was developed based on Hyundai Accent X3 platform with a little change in the body design from Millard Design Australia. In 1994 the mock-up was finalized, and even the several prototypes as the clay model. In 1995 while Timor project has just begun. The Maleo projects that already developed several prototypes in Australia immediately dismissed without a clear reason from the government (Miet Sugiarso: Interview). Speculation spreads that Soeharto's government was preferred to give priority to Timor, the project which was owned by his own son, Tommy Soeharto. Meanwhile, the main reason of Soeharto to guarantee the Timor Project was to make sure that it will face no competitor in national car sedan segmentation (Miet Sugiarso: Interview).

\section{Bakrie Projects}

Another project was developed by Bakrie group. They developed their own national MPV instead of a sedan, the car using multi-sourcing process, assisted by GADAT automotive consultant. GADAT offer the cheap investation to Bakrie with only 120 US\$ to built a new car. The assembly factory using the ex Lippo Nings Pacific facilities in Cikarang, which Bakrie Bought from James Riyadi. The Engine is using Peugeot-PCM Engine, meanwhile, the patent was not actually belonged Peugeot any longer, but the PCM had an authority to sell the engine independently from Peugeot PSA-France. There are 3 kinds of the engine which purposed for Bakrie projects such as:

1. XU $10 \mathrm{~J} 2 \mathrm{U}, \mathrm{SOHC} 2000 \mathrm{cc}$, Gasoline Injection, Normally Aspirated.

2. XU 10J4R, DOHC 2000cc, Gasoline Injection, Normally Aspirated.

3. XUD 9 TF, SOHC $1800 \mathrm{cc}$, Diesel Indirect Injection, Turbocharged Intercooler.

Bakrie has made 10 Prototypes in Indonesia, those prototype designs that were assisted by CAD. Despite Bakrie project were an all-new design, but the size benchmark of Beta97 was Toyota Previa. The car had 3 row and equipped with baggage. It was designed to accommodate "mudik" culture of Indonesian people, with estimation of a family with two children, a servant, 
and a babysitter inside (Suryanto Hariadi: Interview).

There were two variants of Bakrie's car, they were Beta97 and Delta97, both variants used Peugeot engine with different capacity. The Beta 97 was an MPV using 2.0L Peugeot PCM Engine, and the Delta 97 was a Mini-MPV using 1.8L Peugeot PCM Engine. According to Suryanto Hariadi, the size of Beta 97 was quite similar to Toyota Kijang Innova which was launched in 2004, and the size of Delta 97 was similar to Toyota Avanza which was launched in 2005.

\section{Texmaco Perkasa Truck}

Another project developed by PT. Texmaco was owned Marimutu Sinivasan, Texmaco developed a non-passenger truck named "Perkasa", and was based on British Leyland but using 1970s outdated Steyr engine manufacture facilities from Austria. However, Texmaco experienced lack of validation process of their products due to financial issues. The Texmaco project was totally stopped in early 2000 after Marimutu charged for massive corruption in this project (Miet Sugiarso: Interview)

Perkasa project was using the multi-sourcing system in their development, the cabin and chassis were from British Leyland, the front, and rear axle, and the engine was from Steyr (Austria), and the transmission developed by ZF (Germany). Theoretically, their concept was very good to mix all those things into "new species" called Perkasa Truck (Suryanto Hariadi: Interview). PT. Texmaco claimed that they had $75 \%$ of local components in an early stage of development. The target was, $90 \%$ of local components in 2001.

Unfortunately, Sinivasan was reluctant to do a validation test to the prototype, He did not want to spend more on the project. The validation process was essentially needed in every manufacturing process, especially the engine was manufactured by two decades old Steyr manufacturing facilities (Miet Sugiarso: Interview). Aside from validation issues, former Ministry of Industry, Rahardi Ramelan praised Texmaco effort to build a national car, therefore, he (Rahardi Ramelan) persuaded The Army Commander General Wiranto to use Perkasa as the army transportation facility.

However, there are so many technical irregularities when the Texmaco Perkasa being tested by Research and Development of Indonesian Armed Forces (Dislitbang AD). The test was conducted by US army reference. During the test time, the expats decided to use the original components that have been proven, instead of local components made in Subang, Semarang, etc. However, Texmaco Perkasa failed in the downhill test, the engine was overheating and resulted in serious damage to the engine.

This big failure made Brig. General Berlin Hutajulu angry and spontaneously want to rip off the Texmaco certificate, but Berlin got intimidated by an unknown three-star general (Lieutenant General) who 
still wanted to buy 500 units of Texmaco trucks. Nevertheless, until the Texmaco Business collapsed, only 150 units were bought for the army purposes. After Soeharto's fall in 1998, President B.J. Habibie once visited Texmaco factory and privately told Sinivasan to close the factory, because this project had been proven to have many technical irregularities.

In terms of financial, this project had big issues, as it had spent billions of Rupiah through several State-owned Banks by the approval of president Soeharto and BI Governor. In December 1999, this project was terminated as soon as the owner, Marimutu Sinivasan was found guilty and charge for massive corruption against the state.

\section{Conclusion}

The Ersatz capitalists in the auto industry basically got their business license from a personal relationship with government bureaucrats, while their business was based only on the business concession. The capitalists are reluctant to take a risk in research and development and chose to ask for foreign principals technological and capital assistance to face localization policy. The Indonesian capitalists were merely sole agents and an assembler company. Foreign principals are very determinant in the technological research and development. They rule the steps of the local capitalists in innovation, research, and development.

From 1969 to the last 1980s, both the military and Chinese groups were predominant actor who preferred by the foreign (especially Japanese) principals. Not just a predominant actors, but there is a mutual relationship that had been built between both groups. On the one hand, military groups were "indigenous" representatives, as well as the symbol of control and guarantee of the New Order's regime for the foreign principals. On the other hand, military groups tend to backup Chinese groups and their business activity from anti-Chinese sentiments. Military groups need the Chinese because they did not have much capital and business knowledge so they need Chinese groups to get financial aid and also Chinese managerial knowledge to run their business.

The military group's limitation in the business also made them need foreign principals assistance more than any capitalists groups, that is how Kramayudha become the first sole agent which asked Mitsubishi principals to invest in the components localization.

In terms of economic development, Chinese capitalists are important for the regime to accelerate economic growth by their business skill and their good relationship with foreign principals. In the 1990s the military groups declined and Soeharto's family has risen as "new player" in the automotive industry. Just like the military group, Soeharto's family is a representation indigenous capitalists existence, but instead of representing the control of 
regime to the business sectors, it merely shows that Soeharto's political power had been increased significantly.

The local capitalists tend to maintain relationships and determination of foreign principals in order to help them achieve localization. The practice of conglomeration in business also made the brand rationalization policy faced difficulty, due to the inline of foreign principals and local capitalists interest. Without economic rationalization, the economic scale of the auto industry was difficult to be achieved because of the low market purchase on one side, and one the other side the overproduction had caused the industry stuck. The business conglomeration and capital integration with foreign principals were caused independent components business to collapse, seeing the principals preferred to order components from the branch company of their partners.

Since the mid of 1970s the business conglomeration in assembly industries and sole agents was followed by proliferation of their branch component industries, especially in 1976 when foreign principals decided to invest in production facilities of certain components and sub-components in Indonesia and then in 1982 when the government allowed foreign principals to establish main components facilities in Indonesia. It had caused vertical integration to foreign principal in capital and technology. The proliferation of independent components and sub-components industries was decreased and later collapsed as principals and sole agent prefer to use sub-components from their branch company.

The alliance between foreign principals and their domestic partners had caused vertical integration of foreign (Japanese) principals from upstream to downstream industries, and it was a "Total loss" of state's effort to proliferate the national capitalists who are step by step walking in the path towards self-reliance of the automotive industry. After vertical integration in 1982, the state was withdrawn from industrialization plan that had, by Ministry of Industry and BPPT in 1969.

However, there were still several attempts from officials in the assembly companies to built national car projects. Even in the 1990s, several national car projects were developed even though there was no correlation between national car projects and the industrialization plan before 1980s. The Projects in the 1990s were merely sporadic attempts either by private or government institutions without clear direction and massive industrialization plan by the state.

\section{Recommendation for current government's policy}

Until today, the self-reliance in the automotive industry remains a common dream for the Indonesian peoples and government. It remains viewed as a strategic sector that still needs to develop, especially for the largest maritime state like Indonesia, The government still need to develop this sector and 
learn from previous mistakes that had been made in the Soeharto's era. Indonesia needs to restore an independent team to develop the automotive industry, such as "Interdep" Team back in the 1980s, of course with various aspects that need to continue and avoiding aspects that need to avoid from the past. In my view, we can adopt the concept of nowadays KPK (Corruption Eradication Commision).

With such concept, the independent team will have an authority to lead and determine the cooperations between state's institutions to support automotive industrialization. The independent team needs more engagement to the institution, compared to the previous 1970s until 1980s was only engage BPPT and Ministry of Industry. Various State Institution like LIPI, Lemhanas, Ministry of Education, and various top universities like ITB, UGM, and UI need to be involved.

\section{References}

\section{Unpublished Archives (Primary Sources \& State's Documents/Laws)}

Departemen Penerangan RI. 1968. REPELITA I Jilid II.

Instruksi Presiden Republik Indonesia No.2 Tahun 1996 Tentang Pembangunan Industri Mobil Nasional.

Keputusan Presiden Republik Indonesia No.42 tahun 1996 tentang pembuatan Mobil Nasional.

Peraturan Pemerintah No.6 Tahun 1969. Lembar Negara: PP No.7 Tahun 1969.

SK. Menteri Perindustrian RI No. 307/M/SK/8/1976 Arsip Biro Hukum Kementrian Perindustrian Republik Indonesia.

SK Menteri Penggerak Dana Investasi RI/ Ketua BKPM RI No.02/SK/1996.

Undang-Undang No. 1 Tahun 1967 Tentang Penanaman Modal Asing.

\section{Newspapers}

Bisnis Indonesia, 14 Januari 1991

Bisnis Indonesia, 4 Februari 1991

Sinar Harapan, 24 Januari 1980

Sinar Harapan, 26 April 1980

Journal

Aswicahyono, Haryo (2000). "How Not To Industrialise? Indonesia's Automotive Industry.” Bulletin of Indonesian Economic Studies 36 (1), April.

\section{Theses dan Dissertations}

Adnan, Ricardi S (2010). The Shifting Patronage: Dinamika Hubungan Pengusaha dan Penguasa (Dalam Industri Otomotif 1969-1998). (Disertasi Universitas Indonesia, Jakarta).

Wibowo, Wahyu (1998). Aspek-aspek Hukum Inpres No. 2 sebagai Upaya Memasuki Babak Baru Industri Otomotif Nasional. (Tesis Universitas Indonesia, Jakarta).

\section{Books}

Chalmers, Ian (1996). Konglomerasi: Negara dan Modal dalam industri Otomotif 
Indonesia. Jakarta: Penerbit Gramedia.

Robison, Richard (1986). Soeharto \& Bangkitnya Kapitalisme Indonesia. New South Wales: Allen \& Unwin Pty Ltd.

Syamsul Hadi (2005). Strategi Pembangunan Mahatir dan Soeharto. Jakarta: Pelangi Cendekia Publisher.

Sri Bintang Pamungkas (1986). Industri Otomotif Menjelang Tinggal Landas. Jakarta: Yayasan Bina Pembangunan Publisher.

Yahya A Muhaimin (2002). Perkembangan Militer Dalam Politik di Indonesia 19451966. Yogyakarta: Gadjah Mada University Press.

Yoshihara, Kunio (1990). Kapitalisme Semu Asia Tenggara. Jakarta: LP3ES Publisher.

\section{Interviews}

Interview in January 2014 with Ir. Miet Sugiarso (62 years old), Manufacturing manager and head of "Tim AX" Commercial car development Datsun Sena PT. Indokaya Nissan Motor (1976-1982), General Manager of technic and component localization PT. Citra Mobil Nasional (Hyundai Automotive) 1995-1997.

Interview in March 2014 with Prof. Dr.Rahardi Ramelan (74 years old. Minister of Research and Technology of Republic of Indonesia (March 1998 - May 1998), Minister of Industry and Trade (May 1998 - October 1999). Head of Interdepartmental team, Deputy of Automotive BPPT.

Interview with Bloomberg TV, in February 2014 with Soebronto Laras. President Director of PT. Indohero Steel Engineering \& co, President Director PT. Indomobil Utama (1976), President Director of PT. Indomobil

Interview in April 2014 with Adirizal Nizar. Technical Director of PT. Toyota Astra Motor (1990-2002), Supervisor of Toyota Assembly plant, PT. MultiAstra since 1974.

Interview in April 2014 with Ir. Suryanto Haryadi (61 years old). General Manager Of PT. Bakrie Motor (1995-1997), Supervisor Product Development PT. Indomobil Suzuki (1987-1991), Manager Prototype \& Cabin Development PT. Texmaco (1999-2003). 